\title{
Genetic variability and juvenile-adult correlations of Norway spruce (Picea abies) provenances, tested in multisite comparative trials
}

\author{
Marius Budeanu1 ${ }^{\oplus}$, Ecaterina Nicoleta Apostol², Raul Gheorghe Radu', Lucia Ioniță²
}

Budeanu M., Apostol E.N., Radu R.G., Ioniță L., 2021. Genetic variability and juvenile-adult correlations of Norway spruce (Picea abies) provenances, tested in multisite comparative trials. Ann. For. Res. 64(2): 105-122.

Abstract The aim of our study was to analyze the stability traits between 33 Norway spruce provenances tested in five field trials across different environmental conditions, in two major variants of the Romanian Carpathians: outside of the natural distribution range (ONR) and in the natural habitat (INR). To justify the early selection, we selected 40-year-old trees and measured tree height (Th), breast height diameter, pruning height, crown diameter, tree volume, tree slenderness (Ts), pruning height ratio, and crown slenderness, which were then compared on a time series with measurements from trees at 30 and 10 years old, respectively. All provenances reacted to the changes in the environmental conditions, presenting higher Th in the warmer ONR environments, compared with the results of the mountain INR trials, with negative consequences on the stand's stability. In all trials, highly significant differences resulted between, and especially within provenances, suggesting a high potential for adaptation in the future climate change scenario. An analysis of the stability traits suggests that we must avoid ONR afforestation with Norway spruce. All the elite provenances (Marginea, Gurghiu, Comandău, and Sudrigiu), together with Câmpeni and Turda, were highlighted, both for the stability and growth traits, whereas the local provenances and the standard IUFRO provenance were ranked below the average of the trials. The age-age significant correlations and the ranking of the provenances show that no major changes occurred in the last ten years, confirming the backward selection performed at the age of 30 years. The juvenile-mature correlations were also strong but the different evolutions in time of the elite provenances eliminate the possibility of a juvenile selection. The forward selection strategy, for the best trees belonging to the six mentioned provenances, according to Ts, can be applied in the INR trials.

Keywords: adaptability, age-age correlations, field trials, seed sources, tree breeding

Addresses: "Station of Braşov, National Institute for Research and Development in Forestry (INCDS) "Marin Drăcea", Brașov, Romania| 2INCDS “Marin Drăcea", Voluntari, Romania.

Corresponding Author: Marius Budeanu (marius.budeanu@icas.ro).

Manuscript received January 11, 2021; revised December 14, 2021; accepted December 15, 2021. 


\section{Introduction}

In Europe, the Norway spruce (Picea abies (L.) Karst.) is economically important due to the high-growing capacity of the species and the wood quality; however, this species is vulnerable to windstorms (drown rooting) and the specificity of the regeneration, mostly artificial (plantations), which represents two major drawbacks for this species (Jansons et al. 2015, Zeltinš et al. 2019). The climatic perturbations of the last years had a negative influence on the Norway spruce stands stability (Keenan 2015, Steffenrem et al. 2016, Pretzsch et al. 2018, Semeniuc \& Popa 2018). Even if Norway spruce is considered a flexible coniferous species, it can react differently to the changing environmental conditions (Kauppi et al. 2014, Rosner et al. 2014, Boshier et al. 2015). Consequently, testing the adaptation capacity of the different provenances, which will be a seed source in the future, is an important objective for geneticists. The selection of the most productive and well-adapted provenances and their use in similar environmental conditions represent a good practice response to climate change (Ruotsalainen 2014, Keskitalo et al. 2016, Frank et al. 2017, Kapeller et al. 2017), especially for Norway spruce, which regenerates almost exclusively by planting. A gain of a minimum of $20 \%$ in volume production can be obtained by using genetically improved forest reproductive materials in afforestation (Marcu et al. 2020). In Europe, numerous comparative trials were conducted under the coordination of the IUFRO, providing useful information about the most valuable provenances for growth traits, wood quality, and adaptability (Źółciak et al. 2009). Some studies recommend the successive evaluations of the provenances in the same trial, as it can lead to some changes in time concerning the ranking of provenances (Zubizarreta-Gerendiain et al. 2012, Șofletea \& Budeanu 2015). In this regard, identifying the optimal age for backward selection [promoting some provenances in the seed tested category (elite category) according to the results of their descendants] is particularly important in order to reduce the waiting time in the future. The ageage and juvenile--mature correlations, as well as the evolution in time of some provenances help us to accurately establish the optimal moment for backward selection (Hylen 1995, Isik et al. 2010, Hayatgheibi et al. 2018).

In Romania, Norway spruce covers $23.2 \%$ of the countries forests and is the most dominant species in the mountain area (Șofletea \& Curtu 2007). To preserve forest genetic resources (FGR), a dynamic conservation strategy (Koskela et al. 2013) was implemented in 33 European countries (Lefèvre et al. 2013), including Romania. In Romania, 89 FGR were selected for in situ conservation of the Norway spruce (Budeanu et al. 2019). The most valuable provenances are also preserved ex situ, in seed orchards (14) and field trials (34). In Romania, to test the genetic variability and adaptability of 33 Norway spruce provenances (initially selected as untested seed stands) in multisite comparative trials, six open-pollinated progeny trials were established in spring, 1980. In 2010, four of these provenances were designated as tested seed sources (the most important seed stand category) based on the results obtained by their descendants in these trials.

In our study, we aimed to evaluate the genetic variability and age-age correlations of Norway spruce (Picea abies) provenances in five trials (one trial has been decommissioned), when the trees were 40 years old. The following issues were evaluated: i) evaluation and performance comparison of provenances in contrasted environments; ii) optimization of selection strategy (juvenile--mature and trait correlations).

\section{Materials and Methods}

Ten seed-trees were selected from 33 native seed stands of Norway spruce (Figure 1 and Table 1) based on the phenotypic traits [tree height (Th), breast height diameter (Dbh), pruning height $(\mathrm{Ph})]$. The distance between the selected mother trees was up to 50 meters, to minimize the possibility of inbreeding. Seeds 
were collected from each tree and bulked at the provenance level. Five comparative trials were installed in the spring of 1980 to compare the provenances (for growth, quality, and stability traits) and to promote the best of them (backward selection) in the tested seed sources category (elite seed stands). In the early stages of the breeding programs, the progeny tests are used for backward selection (selection of valuable populations by testing their progenies). At the end of the testing program, the trials can be included in the forward selection (the most valuable trees from the best provenances will be included in the future breeding programs).

Three comparative trials (Brețcu, Gurghiu, and Nehoiu) were established in the optimum ecological distribution range of Norway spruce (INR), in the mountain mixed-forests and the other two (Avrig and Târgu Lăpuș) were established outside of the natural distribution range (ONR), at low altitude.

Two trials (Târgu Lăpuș and Gurghiu) were located in the Eastern Carpathians (in the inner part), two in the Curvature Carpathians (Brețcu inner and Nehoiu outside of the curvature), and the last one (Avrig) was situated in the Southern Carpathians, ONR (Figure 1).

The Avrig and Târgu Lăpuş trials were established ONR, in forest lands with medium quality and productivity, while all INR trials were located in mountainous mixed-stands (Norway spruce, silver fir, and European beech) vegetation forests (Table 2).

One replication of the Nehoiu trial was affected by windfalls in the past decade, and as a result, only two viable replications (blocks) remained. No thinning was performed in these trials.

An incompletely balanced $6 \times 6$ square-grid design was implemented in all trials, with 3 replications and 49 seedlings per subdivided plot, planted at 2 by $2 \mathrm{~m}$ spacing, containing all 33 provenances, which consisted of the descendants of open-pollinated seeds. To realize the $6 \times 6$ experimental design, in each replication, three provenances (codes: 1, 2, and 3) were repeated (Șofletea et al. 2012).

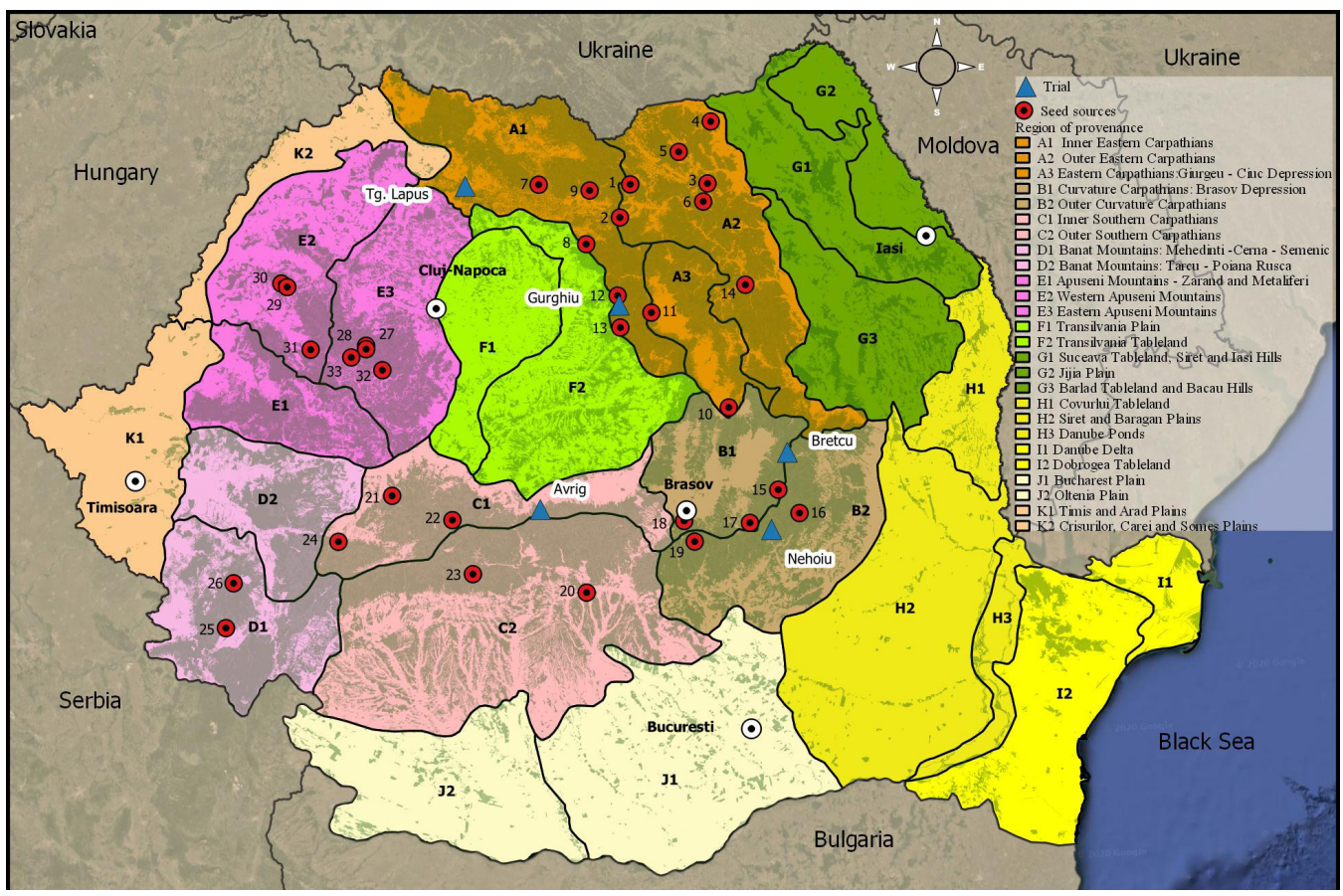

Figure 1 Location of the trials and the tested population's origin. 
Table 1 Provenance origin and the unique code assigned in all trials.

\begin{tabular}{cccccccc}
\hline Code & Provenance name & County & $\begin{array}{c}\text { Altitude } \\
(\mathbf{m})\end{array}$ & Code & $\begin{array}{c}\text { Provenance } \\
\text { name }\end{array}$ & County & $\begin{array}{c}\text { Altitude } \\
(\mathbf{m})\end{array}$ \\
\hline 1 & Coşna & Suceava & 1025 & 18 & Braşov & Braşov & 1020 \\
2 & Dorna Candrenilor & Suceava & 990 & 19 & Azuga & Prahova & 1210 \\
3 & Frasin & Suceava & 755 & 20 & Domnești & Argeș & 650 \\
4 & Marginea & Suceava & 670 & 21 & Orăștie & Hunedoara & 680 \\
5 & Moldovița & Suceava & 855 & 22 & Bistra & Alba & 1350 \\
6 & Stulpicani & Suceava & 985 & 23 & Voineasa & Vâlcea & 1410 \\
7 & Năsăud & Bistrița-Năsăud & 1210 & 24 & Retezat & Hunedoara & 970 \\
8 & Prundul Bârgăului & Bistrița-Năsăud & 1290 & 25 & Bozovici & Caraș-Severin & 600 \\
9 & Rodna & Bistrița-Năsăud & 890 & 26 & Văliug & Caraş-Severin & 940 \\
10 & Sânmartin & Harghita & 900 & 27 & Beliș & Cluj & 1210 \\
11 & Toplița & Harghita & 910 & 28 & Turda & Cluj & 1200 \\
12 & Gurghiu & Mureș & 1225 & 29 & Beiuș & Bihor & 520 \\
13 & Sovata & Mureș & 1190 & 30 & Dobrești & Bihor & 510 \\
14 & Tarcău & Neamț & 930 & 31 & Sudrigiu & Bihor & 1050 \\
15 & Comandău & Covasna & 1150 & 32 & Câmpeni & Alba & 1237 \\
16 & Nehoiu & Buzău & 1120 & 33 & Gârda & Alba & 1295 \\
17 & Nehoiașu & Buzău & 1080 & & & & \\
\hline
\end{tabular}

Note:Codes 1-14: Eastern Carpathian provenances, 15-19: Curvature Carpathians, 20-24: Southern Carpathians, 25-33: Western Romanian Carpathian provenances.

Table 2 Location and environmental conditions of the trials.

\begin{tabular}{|c|c|c|c|c|}
\hline Trial & County/ Forest district & $\begin{array}{l}\text { N Latitude/ } \\
\text { E Longitude/ } \\
\text { Altitude (m) }\end{array}$ & $\begin{array}{l}\text { Exposition/ } \\
\text { Slope Soil }\end{array}$ & $\begin{array}{c}\text { MAT }\left({ }^{\circ} \mathbf{C}\right) / \\
\text { TGS }\left({ }^{\circ} \mathrm{C}\right) \\
\text { SAP }(\mathbf{m m}) / \\
\text { PGS }(\mathbf{m m})\end{array}$ \\
\hline Avrig & Sibiu Avrig & $\begin{array}{c}45^{\circ} 39^{\prime} / 24^{\circ} 26^{\prime} \\
615\end{array}$ & $-/ 0^{\circ}$ eutricambosoil & $8.3 / 16.7680 / 388$ \\
\hline Târgu Lăpuş & Maramureș Târgu Lăpuș & $\begin{array}{c}47^{\circ} 27^{\prime} / 23^{\circ} 52^{\prime} \\
390\end{array}$ & $\begin{array}{l}\text { East/ } 15^{\circ} \\
\text { eutricambosoil }\end{array}$ & $8.7 / 16.0712 / 434$ \\
\hline Brețcu & Covasna Brețcu & $\begin{array}{c}45^{\circ} 58^{\prime} / 26^{\circ} 24^{\prime} \\
1100\end{array}$ & $\begin{array}{l}\text { Northeast/ } 15^{\circ} \\
\text { eutricambosoil }\end{array}$ & $4.8 / 13.4830 / 473$ \\
\hline Gurghiu & Mureș Fâncel & $\begin{array}{c}46^{\circ} 48^{\prime} / 25^{\circ} 04^{\prime} \\
1000\end{array}$ & $\begin{array}{l}\text { North/ } 25^{\circ} \\
\text { eutricambosoil }\end{array}$ & $5.7 / 14.0810 / 462$ \\
\hline Nehoiu & Buzău Siriu & $\begin{array}{c}45^{\circ} 33^{\prime} / 26^{\circ} 17^{\prime} \\
1100\end{array}$ & $\begin{array}{c}\text { East } / 20^{\circ} \\
\text { eutricambosoil }\end{array}$ & $6.1 / 13.6835 / 510$ \\
\hline
\end{tabular}

Note:MAT = mean annual temperature; TGS = average temperature of the growing season; $\mathrm{SAP}=$ sum of the annual precipitations; $\mathrm{PGS}=$ sum of the precipitations of the growing season.

Following the IUFRO methodology (Lines 1967), ten trees were randomly selected in each subdivided plot. Measurements were taken when the trees were 40 years old to determine trees growth and the quality of stem and crown, such as:

-Diameter at breast height (Dbh) was measure using a forest caliper; 
-Trees height (Th) and pruning height $(\mathrm{Ph})$ were taken using a Vertex IV instrument; pruning height is defined as the height from the ground to the first green branch.

-Crown diameter $(\mathrm{Cd})$ projections were measured using an electronic telemeter;

Next, traits were calculated based on the field measurements:

-Tree slenderness index was calculated using the formula: $\mathrm{Ts}=\mathrm{Th} / \mathrm{Dbh}$;

Trees slenderness index (Ts) is important in the evaluation of the stability of Norway spruce stands; an ideal value of Ts is 80 and a value higher than 100 could jeopardize the stability of forests and their resistance to wind and snow damage (Popa 2005).

-Trees volume was calculated using the regression equation method elaborated by Giurgiu et al. (2004);

-Pruning height ratio was calculated using: $\mathrm{Phr}=\mathrm{Ph} / \mathrm{Th} \times 100(\%)$;

-Crown slenderness was calculated using: $\mathrm{Cs}=\mathrm{Th} / \mathrm{Cd}$.

The most important traits for the stands stability (meaning resistance to damage caused by wind and snow) are Ts, Cd and Cs. Lower values for $\mathrm{Ts}$ and $\mathrm{Cd}$ and higher for $\mathrm{Cs}$ are required. Also, higher values for $\mathrm{Ph}$ and $\mathrm{Phr}$ (fewer knots in the wood), but also for growth traits (especially for Dbh) are required. Another important stability trait, survival rate, has not undergone significant changes in the last 10 years, which is why it has not been introduced in the analysis. However, the survival rate influenced the general results at the age of 30 years without significantly influencing the results of the four elite provenances.

The data obtained for all traits were processed using STATISTICA 10.0 (2010) and breedR package (2016) of $\mathrm{R}$ software (2017). The Kolmogorov-Smirnov test was applied to test the normal distribution and the assumptions of ANOVA were verified using Levene's test. In each trial, the total variance was separated due to replications, provenances, their interaction, and the variance of error (residual) by applying the ANOVA test (Nanson 2004).

$$
\mathrm{X}_{\mathrm{ijk}}=\mathrm{m}+\alpha_{\mathrm{i}}+\beta_{\mathrm{j}}+\alpha \beta_{\mathrm{ij}}+\varepsilon_{\mathrm{ijk}}
$$

where: $m$ is the overall average value, $\alpha_{i}$ is a component of $i^{\text {th }}$ replications $(i=1 \ldots \mathrm{a}), \beta j$ is a component of $j^{\text {th }}$ provenances $(j=1 \ldots \mathrm{b})$, $\alpha \beta_{i j}$ is the interaction of $i^{\text {th }}$ replications with $j^{\text {th }}$ provenances and $\varepsilon_{i j k}$ is a random error affecting ijk plots.

The influence of locality and the provenance $\times$ locality interaction were determined with the bifactorial ANOVA model (Nanson 2004).

$$
\mathrm{X}_{\mathrm{ijk}}=\mathrm{m}+\alpha_{\mathrm{i}}+\beta_{\mathrm{j}}+\alpha \beta_{\mathrm{ij}}+\varepsilon_{\mathrm{ijk}}
$$

where: $m$, and $\beta_{j}$ are as described previously, $\alpha_{i}$ is a component of $i^{\text {th }}$ locations $(i=1 \ldots \mathrm{a})$, $\alpha \beta_{i j}$ is the interaction of $i^{\text {th }}$ locations with $j^{\text {th }}$ provenances and $\varepsilon_{i j k}$ is random error.

The ranking of the populations and their homogeneous groups were determined by applying Duncan's test for a 5\% transgression probability ( $\alpha=5 \%)$.

To analyze the opportunity of using non-local seed sources in afforestation, we compared the average Dbh and Th results of the trials with the average values of the Norway spruce natural stands of the forest district where the 5 trials were established, stand with the same age (40 years) and which have benefited from similar environmental conditions (Anonymous 2011, 2016-2019).

In addition, age-age simple and multiple correlations between traits were calculated.

\section{Results}

\section{Site effects}

For all of the analyzed traits, the average trial values differ significantly from one experiment to another (Table 3), which means that the environmental conditions play a particularly important role in the tree phenotypes. In general, no more than two trials were grouped (nonsignificant differences between mean values), the ONR ones for Dbh, tree volume (Tv) and tree slenderness (Ts), and INR for Th (Brețcu, Nehoiu) and Ts (Gurghiu and Nehoiu). The replication factor had a significant influence 
in four trials (except for the Nehoiu trial), which supports the necessity of conducting comparative trials with replications; this is true for all traits. At the same time, the provenance factor played a significant role in three trials (except for Brețcu and Gurghiu). Both in terms of bioaccumulation capacity (Dbh, Tv) and stability (Ts, Cd and Cs), remarkably good results were recorded in the Brețcu test, at the opposite pole being the Gurghiu experiment for growth and the ONR trials for stability.

For the quantitative traits (Dbh, Th, Tv), significant differences $(p<0.05)$ between the average of the trials were registered, with the highest Dbh and Tv results obtained in the Bretcu test, while the highest Th value were registered in ONR trials. For Dbh, the INR average was superior (statistically significant), being 3\% higher than the ONR average, while for Th, the average ONR was 9\% higher, statistically significant (Table 3). The factorial ANOVA analysis (Table 4) shows a highly significant influence of the testing site $(p<0.001)$, provenance and the locality $\mathrm{x}$ provenance interaction, suggesting different reactions of the provenances to the changing of the environmental conditions; this is true for all traits.

The mean value of Ts calculated for all INR trials was 95 , which is $11 \%$ lower (significantly, $p<0.05)$ than the average value registered for the ONR trials. The lowest values of Ts were observed in the Bretcu test $(\mathrm{Ts}=90)$ where all provenances registered average values below the safety threshold (100). In the ONR trials, not a single population in the Târgu Lăpuș trial and only three populations in the Avrig test had Ts values below the safety threshold (Table 3 ). This result forces us to strongly warn against afforestation with Norway spruce outside of its natural area and at low altitudes.

The average $\mathrm{Cd}$ value of the INR trials $(3.76 \mathrm{~m})$ was $3.4 \%$ lower (favorable for stands stability) than the average of the ONR trials, especially because of the results registered in the Bretcu test (Table 3). In the same trial, the Cs also obtained the best result (7.2), which was favorable, with $44 \%$ more than in the Nehoiu test; the last experiment had reduced differences between the two test variants for both crown traits.

The mean value of $\mathrm{Ph}$ calculated for all INR trials was $11.5 \mathrm{~m}$, which is $18 \%$ lower (significantly, $p<0.05$ ) than the average value registered for the ONR trials. The highest values of $\mathrm{Ph}$ were observed especially in the Târgu Lăpuş test (14.7 m). The same situation was registered also for Phr, higher in ONR trials with $13 \%$, compared to the average of INR trials, and with greatest Phr in Târgu Lăpuș experiment, 64\% (Table 3). In all trials and for all traits the effect of the environment is decisive.

Table 3 Mean values ( \pm standard deviation) of spruce provenances in multisite trials.

\begin{tabular}{lcccccccc}
\hline Trials & Dbh (cm) & Th $(\mathbf{m})$ & Tv $\left(\mathbf{m}^{3}\right)$ & Ts & Ph (m) & Phr (\%) & Cd (m) & Cs \\
\hline Avrig & $22.0 \pm 5.0^{\mathrm{c}}$ & $22.5 \pm 2.6^{\mathrm{b}}$ & $0.447 \pm 0.2^{\mathrm{b}}$ & $106 \pm 16^{\mathrm{c}}$ & $13.6 \pm 1.4^{\mathrm{b}}$ & $61 \pm 7^{\mathrm{b}}$ & $3.6 \pm 1.0^{\mathrm{b}}$ & $6.7 \pm 1.7^{\mathrm{b}}$ \\
Târgu & $21.9 \pm 3.2^{\mathrm{c}}$ & $23.1 \pm 2.0^{\mathrm{a}}$ & $0.437 \pm 0.1^{\mathrm{b}}$ & $107 \pm 12^{\mathrm{c}}$ & $14.7 \pm 1.5^{\mathrm{a}}$ & $64 \pm 5^{\mathrm{a}}$ & $4.2 \pm 0.5^{\mathrm{d}}$ & $5.6 \pm 0.7^{\mathrm{c}}$ \\
Lăpuș & & & & & & & & \\
Brețcu & $24.8 \pm 5.1^{\mathrm{a}}$ & $21.6 \pm 2.3^{\mathrm{c}}$ & $0.518 \pm 0.2^{\mathrm{a}}$ & $90 \pm 14^{\mathrm{a}}$ & $11.8 \pm 1.4^{\mathrm{d}}$ & $55 \pm 7^{\mathrm{c}}$ & $3.2 \pm 0.9^{\mathrm{a}}$ & $7.2 \pm 2.2^{\mathrm{a}}$ \\
Gurghiu & $20.4 \pm 4.0^{\mathrm{d}}$ & $19.6 \pm 2.4^{\mathrm{d}}$ & $0.333 \pm 0.2^{\mathrm{c}}$ & $98 \pm 10^{\mathrm{b}}$ & $9.8 \pm 1.6^{\mathrm{e}}$ & $50 \pm 9^{\mathrm{d}}$ & $3.7 \pm 0.8^{\mathrm{c}}$ & $5.5 \pm 0.9^{\mathrm{c}}$ \\
Nehoiu & $22.4 \pm 4.3^{\mathrm{b}}$ & $21.4 \pm 2.4^{\mathrm{c}}$ & $0.432 \pm 0.2^{\mathrm{b}}$ & $97 \pm 11^{\mathrm{b}}$ & $13.0 \pm 1.7^{\mathrm{c}}$ & $61 \pm 6^{\mathrm{b}}$ & $4.4 \pm 0.7^{\mathrm{e}}$ & $5.0 \pm 0.5^{\mathrm{d}}$ \\
\hline
\end{tabular}

Note:Dbh $=$ breast height diameter, $\mathrm{Th}=$ trees' height, $\mathrm{Tv}=$ trees' volume, $\mathrm{Ts}=$ trees' slenderness index, $\mathrm{Ph}=\mathrm{pruning}$ height, $\mathrm{Phr}=$ pruning height ratio, $\mathrm{Cd}=$ crown diameter, $\mathrm{Cs}=$ crown slenderness. Significant differences between trials $(p<0.05)$ were highlighted with different letters $(\mathrm{a}-\mathrm{e})$. 
Table 4 The influence of the testing site and provenances revealed by ANOVA.

\begin{tabular}{|c|c|c|c|c|c|c|}
\hline Factors & Traits & MS* & MSP (\%) & Traits & MS* & $\operatorname{MSP}(\%)$ \\
\hline Locality (L) & Dbh & 2670 & 10 & Th & 1957 & 22 \\
\hline Provenance $(\mathrm{P})$ & & 66 & 2 & & 25 & 3 \\
\hline LX P & & 37 & 5 & & 14 & 5 \\
\hline Error (Trees) & & 18 & 83 & & 5 & 70 \\
\hline Locality (L) & $\mathrm{Tv}$ & 4.69 & 10 & Ts & 52502 & 20 \\
\hline Provenance $(\mathrm{P})$ & & 0.13 & 2 & & 506 & 2 \\
\hline LX P & & 0.07 & 5 & & 340 & 5 \\
\hline Error (Trees) & & 0.03 & 83 & & 156 & 73 \\
\hline Locality (L) & $\mathrm{Ph}$ & 3884 & 57 & $\mathrm{Phr}$ & 31311 & 34 \\
\hline Provenance $(\mathrm{P})$ & & 6.5 & 1 & & 176 & 2 \\
\hline LX P & & 8.1 & 4 & & 131 & 5 \\
\hline Error (Trees) & & 2.1 & 38 & & 45 & 59 \\
\hline Locality (L) & $\mathrm{Cd}$ & 205 & 21 & Cs & 842 & 25 \\
\hline Provenance $(\mathrm{P})$ & & 1.9 & 2 & & 4.3 & 1 \\
\hline LX P & & 1.2 & 4 & & 3.7 & 4 \\
\hline Error (Trees) & & & 73 & & & 70 \\
\hline
\end{tabular}

Note: $\mathrm{Dbh}=$ breast height diameter, $\mathrm{Th}=$ Trees' height, $\mathrm{Tv}=$ Trees' volume, $\mathrm{Ts}=$ Trees' slenderness index, $\mathrm{Ph}=$ pruning height, $\mathrm{Phr}=$ pruning height ratio, $\mathrm{Cd}=$ crown diameter, $\mathrm{Cs}=$ crown slenderness. $\mathrm{MS}$ $=$ mean square, $\mathrm{MSP}=$ mean square participations. ${ }^{*}$ Highly significant influences, at $p<0.001$, were registered for all factors and traits.

\section{Growth traits (Dbh, Th, Tv)}

To test whether growths at the age of 40 years can be accurately predicted from results at age 30 , we compared the rankings of provenances between these two age groups. At age 40, for the ensemble of all trials, the best Dbh, Th and Tv results was registered by the 32 Câmpeni provenance, followed by the tested 12-Gurghiu, whereas the other three elite provenances (4-Marginea, 15-Comandău and 31-Sudrigiu) were ranked in the first half of the ranks. The best of the elite provenances, 12-Gurghiu, was ranked between the first three in the Brețcu, Gurghiu and Avrig trials (Figure 2). For Tv, the 4-Marginea, 15-Comandău and 31-Sudrigiu provenances were ranked 6th, 8th, 16th, respectively. The IUFRO standard provenance, 5-Moldovița, was ranked 12th, while the local provenances were remarked bellow the trials average, except of the Gurghiu experiment. These results are almost similar to those recorded at the age of 30 years (Şofletea \& Budeanu 2015). At the age of 30 years (2010), the results of the four elite provenances were not decisively influenced by the survival rate as they were generally ranked in the middle of the rankings for this important trait. Of the elite provenances, Comandău was especially remarked for its survival rate. In 2010-2020 period, survival rate has not suffered significant changes.

\section{Silvicultural Stability traits (Ts, Cd, Cs)}

For Ts, the best provenances (8-Prundul Bârgăului, 12-Gurghiu and 17-Nehoiașu) were remarkably close to the ideal value, 80 (figure $3)$. Two of the elite provenances (12-Gurghiu and 4-Marginea) presented low Ts values (high stability) in both the Brețcu and Gurghiu trials 


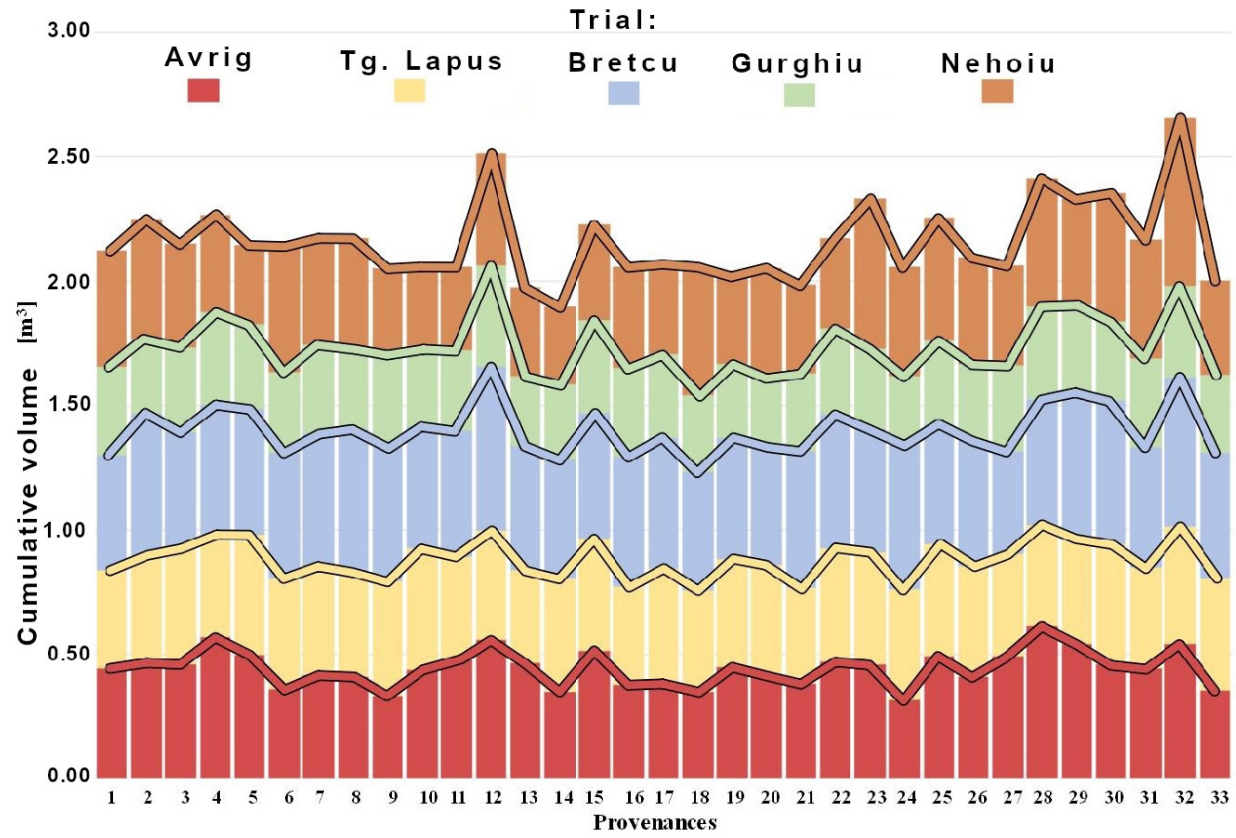

Figure 2 Cumulative average $\mathrm{Tv}$ of the 33 provenances in the five trials.

(ranking among the top five), whereas the other two (15-Comandău and 31-Sudrigiu) recorded values close to the average of the trials (Figure 3). Except for the Gurghiu elite provenance, no other local provenance, not even the standard IUFRO provenance (Moldovița), stood out in terms of stability. In the INR trials, $67 \%$ (in Nehoiu trial) to $100 \%$ (in Brețcu trial) of the provenances registered an average Ts value below the safety threshold (100), whereas in the ONR experiments, except of the three provenances in Avrig test, all the provenances were above the safety threshold (Figure 3 ). This highlights the necessity to formulate distinct recommendations for each trial.

For the ensemble of all trials, two elite provenances (Marginea and Sudrigiu) registered $\mathrm{Cd}$ values equal to the average of the 33 provenances $(3.8 \mathrm{~m})$, and the other two (Comandău and Gurghiu) were higher than the average by $3 \%-5 \%$. The best Cs results of the fourth elite provenances were recorded, once again, by the Marginea population, similar to those determined for Moldovita, the IUFRO standard provenance. At the trial level, in general, the elite provenances, highlighted for the growth traits, also registered high values for $\mathrm{Cd}$ (Figure 4), but they are still in the middle of the rankings. The local provenances obtained results below the average for $\mathrm{Cs}$, and on the average for $\mathrm{Cd}$.

\section{Quality traits (Ph and Phr)}

For the ensemble of all trials, the mean $\mathrm{Ph}$ of provenances varied between 12.1 and $13.0 \mathrm{~m}$, representing $55.4 \%$ to $59.8 \%$ of $\mathrm{Th}$. The high $\mathrm{Phr}$ values were registered by the Nehoiașu, Nehoiu and Braşov provenances. Among the elite provenances, the best at natural pruning were Sudrigiu and Marginea (59\% and 58\%, respectively), whereas the other two provenances, togetherwith the IUFRO provenance(Moldovița), registered the lowest Phr, 55\%-56\% (Figure 4); however, a Phr value higher than 55\%, which was recorded by all provenances, represents one of the highest natural pruning for Norway spruce in Europe (Budeanu et al. 2014). 


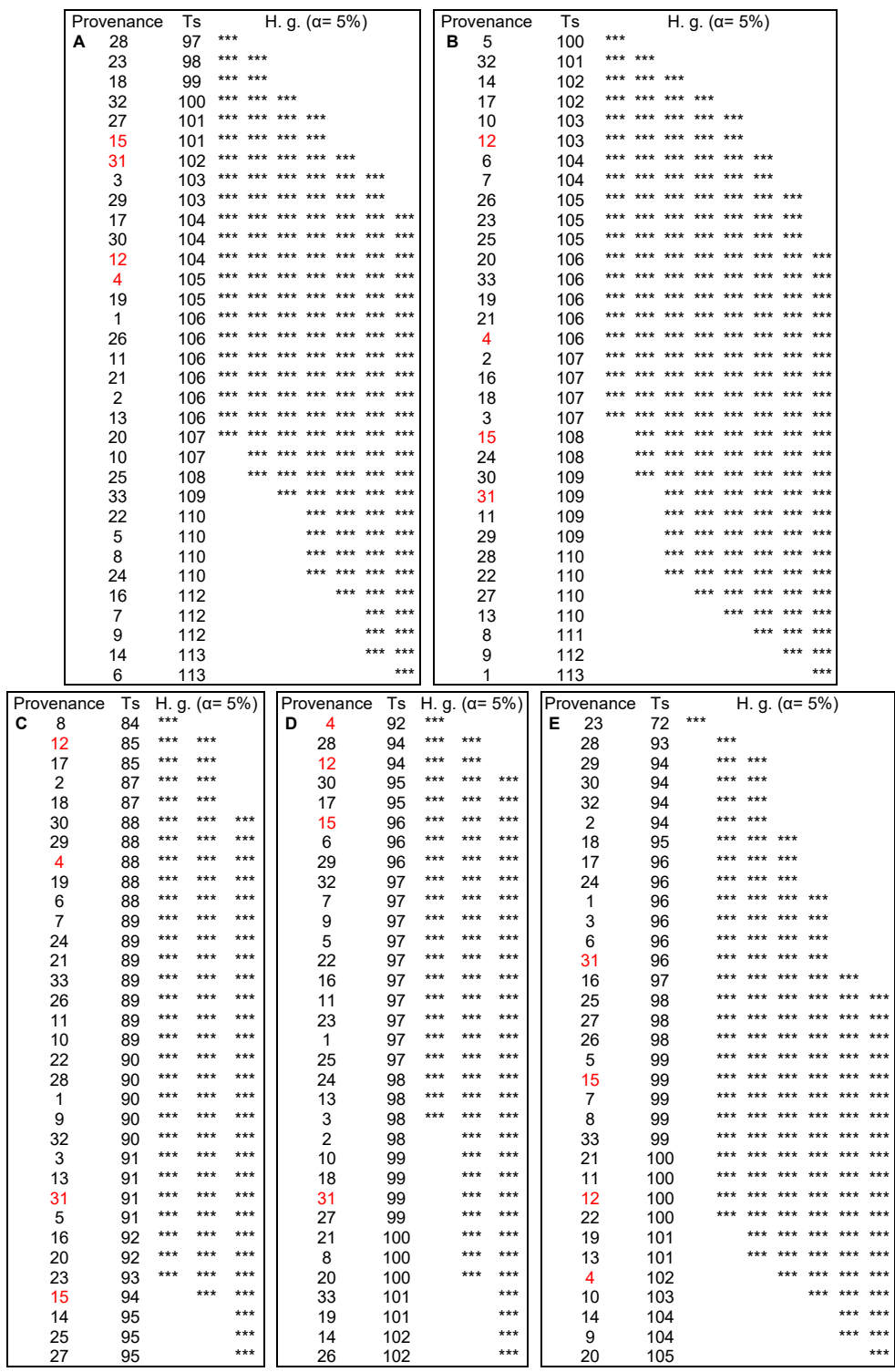

Figure 3 Duncan test for trees' slenderness (Ts) in ONR (A- Avrig, B- Târgu Lăpuş) and INR (C- Brețcu, D- Gurghiu, E- Nehoiu) trials. Homogeneous groups (H. g.) for 5\% transgression probability $(\alpha)$. Provenance codes as in table 1 . Tested provenances, in red.

\section{Comparison with the nearest populations}

Tested provenances registered superior results compared to the trial's average, and when compared to the natural populations from the same forest districts, with the same age (40 years) and benefiting from similar environmental conditions (Anonymous 2011, 2016-2019), the elite provenances obtained higher Dbh and Th values, by $14 \%$ and $16.5 \%$, respectively (Figure 5), with significant differences $(p<0.05)$. 


\begin{tabular}{|c|c|c|c|c|c|c|c|c|c|}
\hline Provenance & $\mathrm{Cd}(\mathrm{m})$ & Provenance & $\mathrm{Cd}(\mathrm{m})$ & Provenance & $\mathrm{Cd}(\mathrm{m})$ & Provenance & $\mathrm{Cd}(\mathrm{m})$ & Provenance & $\mathrm{Cd}(\mathrm{m})$ \\
\hline A 9 & 3.1 & B 11 & 3.9 & C 27 & 2.7 & D 20 & 3.4 & E 14 & 3.8 \\
\hline 14 & 3.2 & 4 & 4.0 & 23 & 2.9 & 19 & 3.4 & 13 & 3.9 \\
\hline 7 & 3.2 & 33 & 4.0 & 33 & 2.9 & 14 & 3.5 & 5 & 3.9 \\
\hline 24 & 3.2 & 21 & 4.0 & 7 & 3.0 & 26 & 3.5 & 10 & 4.0 \\
\hline 10 & 3.2 & 18 & 4.1 & 13 & 3.1 & 8 & 3.5 & 19 & 4.1 \\
\hline 6 & 3.3 & 19 & 4.1 & 31 & 3.1 & 13 & 3.5 & 11 & 4.1 \\
\hline 20 & 3.3 & 32 & 4.1 & 16 & 3.1 & 23 & 3.5 & 7 & 4.2 \\
\hline 16 & 3.3 & 12 & 4.1 & 28 & 3.1 & 18 & 3.6 & 4 & 4.2 \\
\hline 19 & 3.3 & 13 & 4.1 & 25 & 3.1 & 24 & 3.6 & 20 & 4.2 \\
\hline 21 & 3.4 & 23 & 4.1 & 20 & 3.1 & 21 & 3.6 & 22 & 4.3 \\
\hline 8 & 3.4 & 9 & 4.2 & 14 & 3.1 & 27 & 3.6 & 8 & 4.3 \\
\hline 33 & 3.4 & 1 & 4.2 & 10 & 3.1 & 10 & 3.6 & 21 & 4.3 \\
\hline 17 & 3.4 & 2 & 4.2 & 21 & 3.1 & 33 & 3.6 & 27 & 4.3 \\
\hline 26 & 3.5 & 27 & 4.2 & 32 & 3.2 & 22 & 3.6 & 1 & 4.3 \\
\hline 13 & 3.5 & 16 & 4.2 & 1 & 3.2 & 1 & 3.6 & 17 & 4.4 \\
\hline 22 & 3.5 & 14 & 4.2 & 15 & 3.2 & 32 & 3.6 & 9 & 4.4 \\
\hline 2 & 3.6 & 3 & 4.2 & 4 & 3.2 & 2 & 3.6 & 3 & 4.4 \\
\hline 31 & 3.6 & 29 & 4.2 & 11 & 3.2 & 17 & 3.7 & 24 & 4.4 \\
\hline 25 & 3.6 & 5 & 4.2 & 22 & 3.2 & 29 & 3.7 & 15 & 4.4 \\
\hline 1 & 3.6 & 8 & 4.3 & 9 & 3.3 & 31 & 3.7 & 29 & 4.4 \\
\hline 5 & 3.6 & 15 & 4.3 & 26 & 3.3 & 11 & 3.7 & 30 & 4.4 \\
\hline 23 & 3.6 & 6 & 4.3 & 19 & 3.3 & 16 & 3.7 & 16 & 4.4 \\
\hline 18 & 3.6 & 30 & 4.3 & 3 & 3.3 & 25 & 3.7 & 2 & 4.5 \\
\hline 30 & 3.7 & 26 & 4.3 & 29 & 3.4 & 15 & 3.7 & 6 & 4.5 \\
\hline 4 & 3.7 & 24 & 4.3 & 6 & 3.4 & 30 & 3.8 & 33 & 4.5 \\
\hline 11 & 3.7 & 22 & 4.3 & 8 & 3.4 & 3 & 3.8 & 26 & 4.5 \\
\hline 12 & 3.8 & 20 & 4.3 & 17 & 3.4 & 6 & 3.8 & 28 & 4.6 \\
\hline 27 & 3.9 & 17 & 4.3 & 18 & 3.4 & 28 & 3.8 & 12 & 4.6 \\
\hline 3 & 3.9 & 28 & 4.3 & 5 & 3.4 & 7 & 3.8 & 18 & 4.6 \\
\hline 29 & 3.9 & 10 & 4.4 & 2 & 3.6 & 5 & 3.8 & 31 & 4.6 \\
\hline 32 & 3.9 & 31 & 4.4 & 12 & 3.7 & 9 & 3.9 & 25 & 4.7 \\
\hline 15 & 4.0 & 7 & 4.6 & 24 & 3.7 & 4 & 4.0 & 23 & 4.9 \\
\hline 28 & 4.3 & 25 & 4.3 & 30 & 3.7 & 12 & 4.0 & 32 & 5.0 \\
\hline Provenance & $\operatorname{Phr}(\%) \mathrm{F}$ & Provenance & $\operatorname{Phr}(\%)$ & \multicolumn{2}{|c|}{ Provenance Phr(\%) } & Provenance & $\mathrm{Phr}(\%)$ & Provenance & $\operatorname{Phr}(\%)$ \\
\hline A 14 & 66.2 & B 31 & 67.4 & C 23 & 58.6 & D 19 & 54.8 & E 17 & 65.4 \\
\hline 20 & 64.8 & 16 & 67.2 & 25 & 58.4 & 31 & 53.8 & 16 & 63.9 \\
\hline 8 & 63.9 & 32 & 67.0 & 31 & 57.9 & 27 & 53.8 & 27 & 63.5 \\
\hline 7 & 63.4 & 18 & 66.8 & 14 & 57.6 & 20 & 53.5 & 7 & 63.4 \\
\hline 23 & 63.2 & 33 & 66.5 & 19 & 57.4 & 17 & 52.9 & 12 & 63.2 \\
\hline 18 & 62.9 & 17 & 66.0 & 18 & 57.2 & 16 & 52.9 & 29 & 62.9 \\
\hline 19 & 62.8 & 25 & 65.5 & 27 & 56.8 & 10 & 52.8 & 30 & 62.8 \\
\hline 6 & 62.8 & 24 & 65.4 & 20 & 56.5 & 7 & 52.7 & 11 & 62.7 \\
\hline 10 & 62.8 & 1 & 64.9 & 11 & 56.5 & 13 & 52.4 & 15 & 62.5 \\
\hline 21 & 62.3 & 4 & 64.8 & 3 & 56.1 & 33 & 52.2 & 6 & 62.5 \\
\hline 22 & 61.5 & 8 & 64.8 & 4 & 56.0 & 26 & 51.9 & 2 & 62.1 \\
\hline 17 & 61.5 & 23 & 64.8 & 22 & 55.7 & 29 & 51.3 & 24 & 61.9 \\
\hline 9 & 61.3 & 21 & 64.4 & 28 & 55.5 & 2 & 51.1 & 9 & 61.9 \\
\hline 4 & 61.2 & 27 & 64.4 & 7 & 55.5 & 28 & 51.0 & 22 & 61.7 \\
\hline 26 & 61.1 & 11 & 64.3 & 16 & 55.5 & 18 & 51.0 & 33 & 61.7 \\
\hline 16 & 61.1 & 14 & 64.1 & 32 & 55.1 & 25 & 50.6 & 13 & 61.3 \\
\hline 29 & 61.0 & 29 & 64.0 & 17 & 55.0 & 32 & 50.4 & 14 & 61.2 \\
\hline 24 & 61.0 & 15 & 63.9 & 13 & 55.0 & 23 & 50.3 & 5 & 61.1 \\
\hline 1 & 60.9 & 28 & 63.6 & 21 & 54.9 & 24 & 50.0 & 21 & 61.1 \\
\hline 5 & 60.5 & 3 & 63.6 & 6 & 54.9 & 1 & 50.0 & 23 & 60.9 \\
\hline 2 & 60.4 & 30 & 63.5 & 33 & 54.8 & 8 & 49.8 & 18 & 60.9 \\
\hline 30 & 60.2 & 10 & 63.3 & 2 & 54.5 & 5 & 49.3 & 4 & 60.8 \\
\hline 31 & 60.0 & 7 & 63.3 & 10 & 54.3 & 6 & 49.2 & 28 & 60.7 \\
\hline 3 & 59.8 & 9 & 63.2 & 1 & 54.2 & 11 & 48.8 & 19 & 60.5 \\
\hline 11 & 59.6 & 22 & 63.1 & 8 & 54.1 & 22 & 48.7 & 10 & 60.3 \\
\hline 12 & 59.4 & 26 & 63.1 & 9 & 53.3 & 30 & 48.7 & 3 & 60.2 \\
\hline 13 & 59.4 & 13 & 63.0 & 15 & 53.2 & 21 & 48.4 & 26 & 60.2 \\
\hline 32 & 58.6 & 2 & 61.9 & 5 & 52.6 & 9 & 48.3 & 8 & 59.6 \\
\hline 33 & 58.4 & 20 & 61.8 & 30 & 52.5 & 14 & 47.9 & 25 & 58.8 \\
\hline 27 & 58.1 & 19 & 61.7 & 24 & 52.2 & 12 & 46.9 & 1 & 58.3 \\
\hline 15 & 57.7 & 6 & 60.2 & 26 & 52.0 & 3 & 46.9 & 20 & 57.0 \\
\hline 25 & 57.5 & 12 & 60.1 & 29 & 51.9 & 15 & 46.8 & 32 & 55.0 \\
\hline 28 & 56.1 & 5 & 59.1 & 12 & 50.0 & 4 & 46.6 & 31 & 51.6 \\
\hline
\end{tabular}

Figure 4 Ranking of the provenances for crown diameter (Cd, up) and pruning height ratio (Phr, down) in ONR (A- Avrig, B- Târgu Lăpuș) and INR (C- Brețcu, D- Gurghiu, E- Nehoiu) trials. Provenance codes as in table 1 . Tested provenances, in red.

\section{Age-age correlations and the behavior of} provenances in time

The last decade's correlations (Table 5) suggest the possibility for earlier selection, at the age of 30 years. The highest correlation was found between Dbh 2020 and Dbh 2010, Ts 2020 and
Ts 2010 and between Cd 2020 and Cd 2010, these traits could be chosen in the selection process.

The juvenile-adult correlations (1990-2020), which are only available for three trials, Avrig, Gurghiu and Nehoiu (Enescu \& Ioniță 2002), and only for growth traits (Figure 6), indicates the possibility of a very early selection, especially 

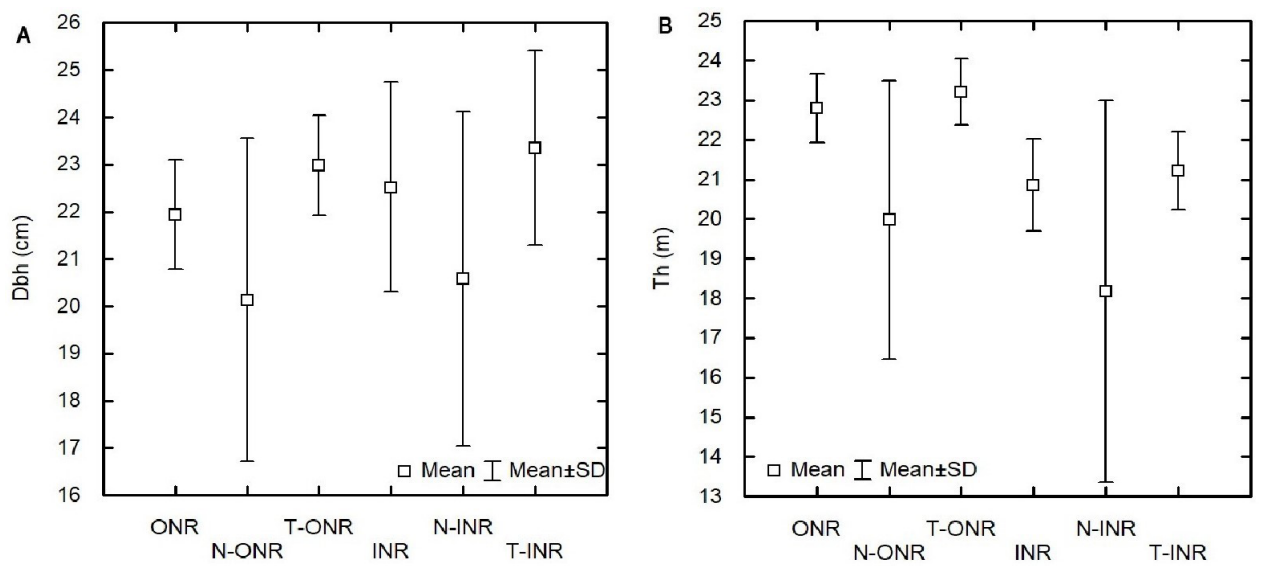

Figure 5 The comparison between ONR and INR trials, tested provenances (T-ONR, T-INR) and nearest populations (N-ONR, N-INR) for breast height diameter (Dbh, left) and trees' height (Th, right).

for Dbh, but this choice could be very risky because there are many provenances with low growth in the juvenile period, growth that activates after 30 years. For instance, in the Gurghiu trial in 1990, the Brașov provenance was ranked third for Dbh, while in 2020 was ranked 23rd. The elite Marginea and Comandău provenances obtained the opposite results, which went up from 16th and 14th to the third and fifth positions. At the same time, the Gurghiu elite provenance remained in first place, whereas Sudrigiu remained in ranked 9th. For Th, the local and elite provenance, Gurghiu, remained at the top of the rankings, even with a slight rise, from seventh to third place. The other elite provenance, Sudrigiu, remained on to the top (from first to the second position), whereas the Marginea elite provenance dropped from $4^{\text {th }}$ to $14^{\text {th }}$. The Comandău provenance improved from rank 26 to rank 10. The standard IUFRO provenance, Moldoviţa, remained in the middle of the ranking for Dbh, and dropped from rank 10 to 25 , in terms of Th value.

Prudence is further strengthened if we follow the evolution on the Nehoiu test, where, in 1990, the standard IUFRO provenance, Moldovița, occupied the first position for Dbh, but dropped in time, reaching rank 31 today (out of the 33 provenances). With equally bad results, for Th, Moldovița dropped from rank 2 to 33, from 1990 to 2020. For Dbh, the Marginea and Comandău elite provenances dropped in ranking (from 3 and 5 to 22 and 21, respectively), whereas Sudrigiu and Gurghiu went up (from 23 and 24 to 10 and 13 , respectively). The same trend was registered for Th, with a steeper evolution for Marginea (from 1 to 14) and Gurghiu (from 22 to 6). The local provenances, Nehoiașu and Nehoiu, did not register spectacular evolutions in time, remaining in the last third of the rankings, both for Dbh and Th.

In the Avrig ONR trial, for Dbh, the four elite provenances exhibited a different behavior over time. Gurghiu remained at the top and went up (from 10 to 2), Marginea and Comandău climbed spectacularly (from 16 and 22 to 4 and 6 , respectively), whereas Sudrigiu provenance remained in the middle of the ranking. For Th, three of the elite provenances (except Comandău, which was maintained above, but with a slight descent, from 3 to 9) went up in the rankings, with accelerated evolution for Marginea (from the 33 to 3) and Gurghiu (from 26 to 1).

The standard IUFRO provenance, Moldovița, climbed slightly in time, from 9 to 6 for Th, and from 14 to 10 , for Dbh. The local provenance, Bistra, did not register spectacular evolutions in time, remaining in the middle of the rankings, for Dbh, and in the first third, for Th. 
Table 5 Age-to-age mean correlations (2010 vs. 2020) between analyzed traits in ONR and INR.

\section{Average ONR trials}

\begin{tabular}{lcrrrrrrr} 
Variables & Dbh_10 & \multicolumn{1}{c}{ Th_10 } & \multicolumn{1}{c}{ Tv_10 } & \multicolumn{1}{c}{ Ts_10 } & Ph_10 & Phr_10 & Cd_10 & \multicolumn{1}{c}{ Cs_10 } \\
\hline Dbh_20 & $\mathbf{0 . 7 1}$ & $\mathbf{0 . 4 1}$ & $\mathbf{0 . 6 6}$ & $\mathbf{- 0 . 4 9}$ & 0.10 & -0.16 & $\mathbf{0 . 6 4}$ & $\mathbf{- 0 . 3 4}$ \\
Th_20 & $\mathbf{0 . 5 1}$ & $\mathbf{0 . 6 9}$ & $\mathbf{0 . 6 0}$ & 0.02 & $\mathbf{0 . 4 9}$ & 0.15 & $\mathbf{0 . 4 5}$ & -0.03 \\
Tv_20 & $\mathbf{0 . 7 3}$ & $\mathbf{0 . 5 5}$ & $\mathbf{0 . 7 3}$ & $\mathbf{- 0 . 3 4}$ & 0.24 & -0.07 & $\mathbf{0 . 6 0}$ & -0.26 \\
Ts_20 & $\mathbf{- 0 . 4 5}$ & 0.10 & -0.30 & $\mathbf{0 . 7 2}$ & 0.31 & 0.33 & -0.55 & $\mathbf{0 . 5 7}$ \\
Ph_20 & 0.19 & $\mathbf{0 . 4 2}$ & 0.24 & 0.21 & $\mathbf{0 . 4 2}$ & 0.23 & -0.15 & $\mathbf{0 . 5 0}$ \\
Phr_20 & $\mathbf{- 0 . 3 5}$ & -0.26 & $\mathbf{- 0 . 3 6}$ & 0.31 & -0.06 & 0.08 & $\mathbf{- 0 . 7 2}$ & $\mathbf{0 . 6 0}$ \\
Cd_20 & $\mathbf{0 . 8 2}$ & $\mathbf{0 . 4 7}$ & $\mathbf{0 . 7 7}$ & $\mathbf{- 0 . 8 0}$ & -0.09 & $\mathbf{- 0 . 4 3}$ & $\mathbf{0 . 8 1}$ & $\mathbf{- 0 . 6 7}$ \\
Cs_20 & $\mathbf{- 0 . 4 0}$ & 0.11 & -0.32 & $\mathbf{0 . 7 1}$ & $\mathbf{0 . 5 6}$ & $\mathbf{0 . 6 2}$ & $\mathbf{- 0 . 6 4}$ & $\mathbf{0 . 7 8}$ \\
\hline
\end{tabular}

\section{Average INR trials}

\begin{tabular}{lcrrrrrrr} 
Variables & \multicolumn{1}{c}{ Dbh_10 } & \multicolumn{1}{c}{ Th_10 } & \multicolumn{1}{c}{ Tv_10 } & \multicolumn{1}{c}{ Ts_10 } & \multicolumn{1}{c}{ Ph_10 } & \multicolumn{1}{c}{ Phr_10 } & \multicolumn{1}{c}{ Cd_10 } & \multicolumn{1}{c}{ Cs_10 } \\
\hline Dbh_20 & $\mathbf{0 . 7 5}$ & $\mathbf{0 . 3 7}$ & $\mathbf{0 . 7 0}$ & $\mathbf{- 0 . 6 2}$ & -0.19 & $\mathbf{- 0 . 4 0}$ & $\mathbf{0 . 5 9}$ & $\mathbf{- 0 . 4 7}$ \\
Th_20 & $\mathbf{0 . 7 0}$ & $\mathbf{0 . 5 8}$ & $\mathbf{0 . 7 1}$ & $\mathbf{- 0 . 4 3}$ & 0.09 & -0.17 & $\mathbf{0 . 6 0}$ & $\mathbf{- 0 . 4 2}$ \\
Tv_20 & $\mathbf{0 . 7 6}$ & $\mathbf{0 . 4 3}$ & $\mathbf{0 . 7 4}$ & $-\mathbf{0 . 5 7}$ & -0.12 & $\mathbf{- 0 . 3 5}$ & $\mathbf{0 . 5 6}$ & $\mathbf{- 0 . 4 4}$ \\
Ts_20 & $\mathbf{- 0 . 4 7}$ & -0.04 & $\mathbf{- 0 . 3 8}$ & $\mathbf{0 . 5 7}$ & $\mathbf{0 . 4 0}$ & $\mathbf{0 . 4 9}$ & $\mathbf{- 0 . 3 5}$ & $\mathbf{0 . 3 5}$ \\
Ph_20 & 0.17 & 0.26 & 0.16 & -0.06 & 0.31 & 0.23 & 0.20 & -0.10 \\
Phr_20 & $\mathbf{- 0 . 3 5}$ & -0.17 & $\mathbf{- 0 . 3 6}$ & 0.28 & 0.23 & $\mathbf{0 . 3 5}$ & -0.20 & 0.19 \\
Cd_20 & $\mathbf{0 . 4 2}$ & 0.17 & $\mathbf{0 . 4 0}$ & $\mathbf{- 0 . 4 2}$ & $\mathbf{- 0 . 3 8}$ & $\mathbf{- 0 . 5 2}$ & $\mathbf{0 . 4 8}$ & $\mathbf{- 0 . 4 7}$ \\
Cs_20 & -0.10 & 0.14 & -0.06 & 0.26 & $\mathbf{0 . 5 3}$ & $\mathbf{0 . 5 6}$ & -0.22 & 0.31 \\
\hline
\end{tabular}

Note: $\mathrm{Dbh}=$ breast height diameter, $\mathrm{Th}=$ Trees' height, $\mathrm{Tv}=$ Trees' volume, $\mathrm{Ts}=$ Trees' slenderness index, $\mathrm{Ph}=\mathrm{Pruning}$ height, $\mathrm{Phr}=$ Pruning height ratio, $\mathrm{Cd}=$ crown diameter, $\mathrm{Cs}=$ crown slenderness. Significant correlations are marked in bold.

\section{Discussion}

To increase the resistance of Norway spruce to windfalls and snow breaks, it is recommended to avoid monocultures and plant this species at lower-density planting and in a mixture with silver fir and European beech (Gardiner \& Quine 2000, Badea et al. 2015, Suvanto et al. 2019, Samariks et al. 2020, Šilinskas et al. 2020, Bosela et al. 2021). For south-western Germany, recommendations have even been made to replace Norway spruce with silver fir (especially at higher altitudes), the latter being more resistant to previous drought extremes (Van der Maaten-Theunissen et al. 2013, Vitali et al. 2017).

In this study, we analyzed the behavior of the progenies from 33 seed sources of Norway spruce, in five multisite comparative trials (at the age of 40 years), with an emphasis on the four provenances highlighted in the previous evaluation (at 30 years old). Along with the data at 10 years old, we tried to analyze the evolution in time of these provenances compared to the local provenances and with an IUFRO provenance, in order to identify the optimal age for backward selection. A particularly important trait in the breeding program is the survival rate which has not undergone significant changes in the last 10 years. At the age of 30 years (2010), the results of the four elite provenances were not decisively influenced by the survival rate as they were generally ranked in the middle of the rankings for this important trait.

The wide diversity of performances (with slow or fast-growing, specialized and generalist, stable and less stable) of the 33 populations (and especially within them) is favorable for adaptation to the changing climatic conditions. In a warmer climate and benefit from a longer growing season, the competition of the 33 provenances for light has intensified [the trees grow too tall and too quickly; 


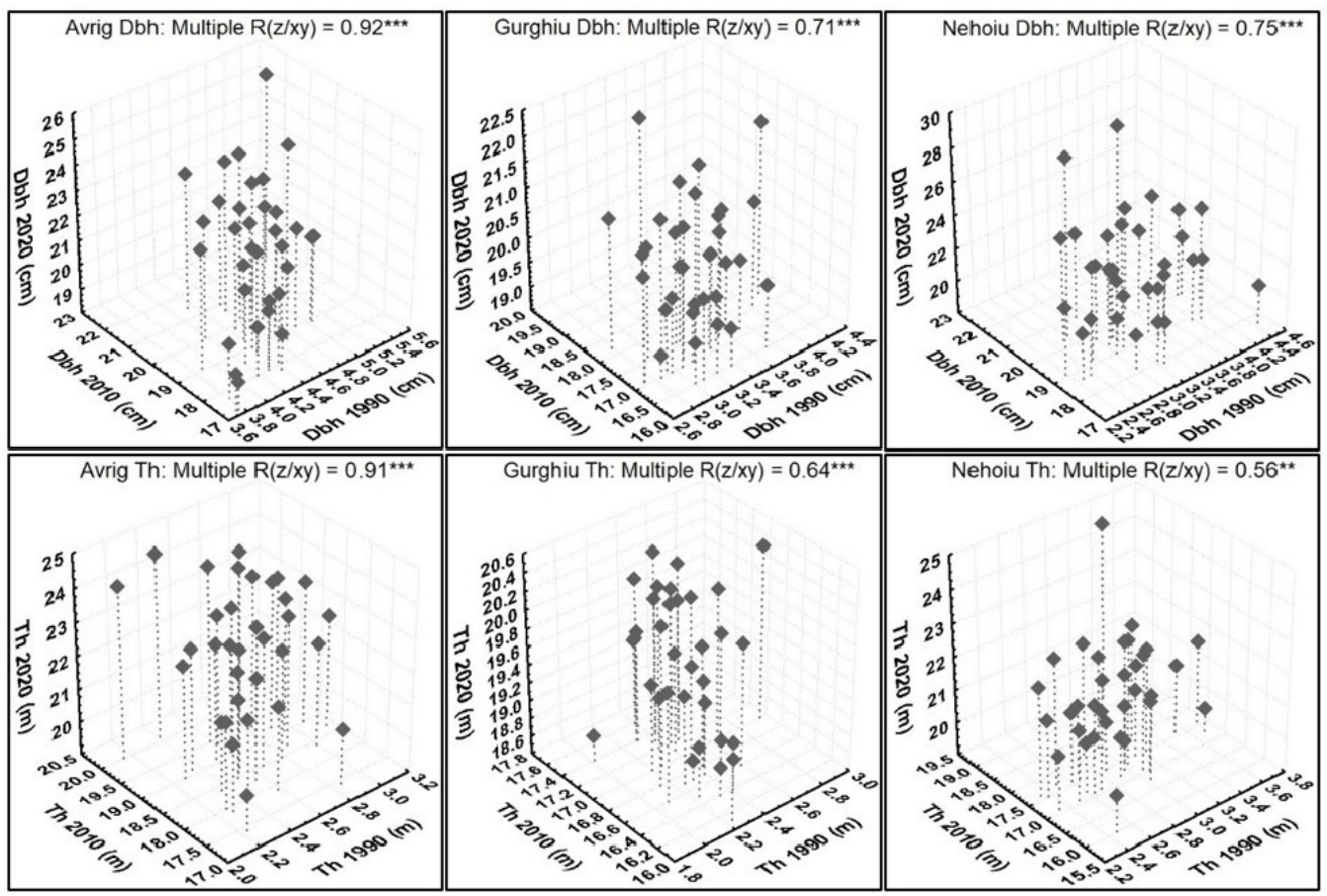

Figure 6 Juvenile-mature multiple correlations for Dbh (up) and Th (down).

similar results registered in Latvia (Zeltinš et al. 2019)], given that no thinning has been made in these trials so far. If two thinning had been made (at 20 and 30 years), the competition would have reduced (lower Ts values). Unfortunately, previous concerns about the Câmpina ONR trial came true, as it was destroyed by the wind, in 2016. Following general findings (Chen 2016), we found that Genotype $x$ Environment interaction was stronger for growth traits (Dbh and $\mathrm{Th}$ ) than for quality traits.

For growth traits (Dbh, Th, Tv), the Romanian provenances of Norway spruce were previously remarked in several European countries, including France (Héois \& Van De Sype 1991), Bulgaria (Alexandrov \& Stancova 1997) and Hungary (Ujvari E. \& Ujvari F. 2006); the latest data comes from Latvia, where the Dorna Candrenilor provenance was ranked first, beyond the 45 provenances, for $\mathrm{Tv}$, at an age of 32 years (Zeltinš et al. 2019). In our research, Dorna Candrenilor was ranked 10th (for the ensemble of all trials), with a remarkable behavior in Brețcu and Nehoiu INR trials. In Lithuania, at an age of 35 years, a negative correlation between Dbh and knot diameter was obtained (Šilinskas et al. 2020), with a favorable impact on wood quality, which recommends the use of Dbh in selection. In Norway, because of the high correlation between $\mathrm{Th}$ and the number of damaged trees, it was also recommended to avoid selection by Th (Skrøppa \& Steffenrem 2019). Also, our research leads to the recommendation of the Dbh trait for selection, after the stability traits (Ts, Cd, Cs). At the age of 40 years, a negative correlation was observed between Dbh and Ts (data not shown), the latter being in a direct correlation with Cs. In this situation, the forward breeding strategy could consider selection after Ts (choosing trees with the lowest Ts values). As the value of Ts decreases, the trees have larger volumes and slender crowns. 
For the stability traits, the best values were registered in the Brețcu INR trial, whereas in ONR tests, the danger of windthrow is extremely high, especially due to the Ts values, which exceeded the threshold of 100. It is recommended to avoid planting Norway spruce outside the natural area, at low altitudes. In Latvia (Snepsts et al. 2020), trees with a similar Dbh but a higher Th (resulting in a higher Ts) were more vulnerable to wind damage. Values close to the Ts result (90) of the Brețcu test were registered in trials with medium environmental conditions and close to the Bretcu trees' age: 89 in Norway (Steffenrem et al. 2020), and 86 in France (Loubère et al. 2004). We expected the lowest values for $\mathrm{Cd}$ (favorable for stands stability) to be recorded at the provenances from the Apuseni Mountains (a division of the Western Romanian Carpathians), area known for the existence of narrow-crowned Norway spruce ideotypes (Pârnuță 2008); however, the populations originating from the Apuseni mountains stood out only in the Brețcu test (first position), otherwise, they were ranked last three times.

Regarding the quality traits, all provenances obtained a Phr higher than 55\%. Among the elite provenances, Sudrigiu stood out, followed by Marginea. A Phr of 50\% has been reported previously in Romania, both in provenance trials, at the same age (Mihai 2009) and also in natural populations (Florescu et al. 2002). A lower Phr mean value was registered in Sweden, 22\%, and at an age of 66 years (Petersson 1997). In Romania, recent studies concerning the resonance wood for the manufacture of musical instruments (Dinulică et al. 2015, Albu et al. 2020) highlighted the possibility to use less-pruned stems and with higher knottiness, if the knots are grouped into the whorls and the distance between the whorls is long enough.

The age-age correlations indicate that no major changes occurred in the last ten years, confirming the backward selection performed at the age of 30 years. The four elite provenances have remained at the top of the rankings, allowing us to maintain the populations they come from in the category of tested seed sources. The juvenile-mature correlations were also high, especially for $\mathrm{Dbh}$, for which, the Dbh correlations (from 10,30 , and 40 years) were highly significant (0.71-0.92), compared to the 0.56 and 0.64 values registered for $\mathrm{Th}$ in the Nehoiu and Gurghiu experiments, respectively. High juvenile-mature correlations were registered in Germany, at the same age and planting density $(2 \mathrm{~m} \times 2 \mathrm{~m})$ of a clonal test (Isik et al. 2010). In all our trials, different evolutions in time were obtained for the 33 provenances, which eliminates the possibility of juvenile selection. According to Dbh, except for the Gurghiu (only in Gurghiu trial), and Comandău (in Nehoiu test), all elite provenances would have been excluded from a possible selection made in the juvenile stage. Except for Gurghiu provenance, all other local provenances recorded $\mathrm{Dbh}$ and $\mathrm{Th}$ results below to the trials average also in the juvenile stage, as were recorded at 30 and 40 years. In Germany (Isik et al. 2010), at a rotation period of 60 years, the selection efficiency for Th was maximized at age 17, in the juvenile period. Extrapolating to our rotation period (110 years), we could reach the selection age indicated by us, 30 years. In Norway, for wood density, the selection age was 28 years (Hylen 1995). In Sweden, for a wood trait (microfibril angle), the high heritability allows the selection in juvenile stage, at 21 years old (Hayatgheibi et al. 2018).

The future research direction could follow to investigate the genetic differences between provenances and the comparison of the QST and FST coefficients of genetic diversity. In Romania, the magnitude of the annual height growths of Norway spruce in the warmer environmental conditions of the last 30 years could be investigated, because in Sweden the height growths of the mentioned period was 9.5\% higher than expected (Mensah et al. 2021). 


\section{Conclusions}

All the elite provenances (Marginea, Gurghiu, Comandău, and Sudrigiu), together with Câmpeni and Turda, were highlighted, both for stability and growth traits, while the local provenances and the standard IUFRO provenance obtained results below the average of the trials. Due to the very high environmental variability between trials, the provenance participation do not exceed $3 \%$ of the overall variation.

The age-age correlations and the ranking of the provenances show that no major changes occurred in the last ten years, confirming the backward selection performed at the age of 30 years. Even though the juvenile traits generally predict the adult traits well $(r>0.70)$, the few very best provenances differed at the juvenile relative to the adult stages, suggesting that it is preferred to wait until 30 years of age to make the backward selection.

All 33 provenances reacted to the changing of the environmental conditions, presenting higher Th in the warmer ONR environments, compared with the results of the mountain INR trials, with negative consequences on the stand's stability, which requires maximum caution in the movement of forest reproductive materials. Inside of the trials, highly significant differences were found between provenances and especially within them, suggesting a high potential for adaptation in the future climatic change. The trees' stability traits suggest the necessity to avoid the ONR afforestation with Norway spruce, at low altitude. All these recommendations should be considered in future forest strategy and disseminated to the stakeholders.

\section{Acknowledgements}

This paper was financed by the Romanian Ministry of Research, Innovation and Digitalization, in the frame of Nucleu Programme contracted with National Institute for Research and Development in Forestry "Marin Drăcea"
(Project PN19070302). We wish to thank our devoted colleagues: Dan Pepelea, Ştefan Tănasie, Ioana Maria Pleşca, Mihaela Vieru and Gabriela Grosu, for their help in the field measurements.

\section{References}

Albu C.T., Dinulică F., Bartha S., Vasilescu M.M., Tereșneu C.C., Vlad I.A., 2020. Musical instrument lumber. BioResources 15: 967-986. https://doi.org/10.15376/ biores.15.1.967-986

Alexandrov A., Stancova T., 1997. Norway spruce provenance trials in Bulgaria. In: IUFRO "Norway spruce symposium", Stara Lesna, Slovakia, 8 p.

Anonymous, 2011. Management plan of Fâncel Forest District, Production unit 3 Tireu. INCDS Manuscript [in Romanian].

Anonymous, 2016. Management planof Avrig Forest District, Production unit 4 Sebeș. INCDS Manuscript [in Romanian].

Anonymous, 2017. Management plan of Siriu Forest District, Production unit 6 Cașoca. INCDS Manuscript [in Romanian].

Anonymous, 2018. Management plan of Brețcu Forest District, Production unit 6 Oituz. INCDS Manuscript [in Romanian]. Anonymous, 2019. Management plan of Târgu Lăpuş Forest District, Production unit 2 Stoiceni. INCDS Manuscript [in Romanian]. Badea O., Dumitru I., Cojocia C., Popa, I., 2015. The radial growth-competition relationship in Picea abies stands affected by windfall. Dendrobiology 73: 175-181. https://doi.org/10.12657/denbio.073.018

Bosela M., Tumajer J., Cienciala E., Dobor L., et al., 2021. Climate warming induced synchronous growth decline in Norway spruce populations across biogeographical gradients since 2000. Science of the Total Environment 752: 141794. https://doi. org/10.1016/j.scitotenv.2020.141794

Boshier D., Broadhurst L., Cornelius J., Gallo L., Koskela J., Loo J., Petrokofsky G., St Clair B., 2015. Is local best? Examining the evidence for local adaptation in trees and its scale. Environmental Evidence 4: 20. https:// doi.org/10.1186/s13750-015-0046-3 
BreedR, 2016. An open statistical package to analyse genetic data (WP6). http://famuvie. github.io/breedR/ (accessed on 6 September, 2020).

Budeanu M., Popescu F., Şofletea N., 2019. In situ conservation of forest genetic resources in Romania. In: Šijačić-Nikolić M., Milovanović J., Nonic M. (Eds.), Forests of southeast Europe under a changing climate. Conservation of genetic resources. Springer International Publishing, Switzerland, pp. 195-205.

Budeanu M., Şofletea N., Petriţan I.C., 2014. Among-population variation in quality traits in two Romanian provenance trials with Picea abies L. Baltic Forestry 20: 37-47.

Chen Z.-Q., 2016. Quantitative genetics of Norway spruce in Sweden. PhD Thesis. Swedish University of Agricultural Sciences, Umeå, Sweden. https://pub.epsilon.slu. se/13331/1/chen z 160502.pdf

Dinulică F., Albu C.T., Borz S.A., Vasilescu M.M., Petrițan I.C., 2015. Specific structural indexes for resonance Norway spruce wood used for violin manufacturing. BioResources 10: 7525-7543. https://doi.org/10.15376/ biores.10.4.7525-7543

Enescu V., Ioniţă L., 2002. Inter and intra populations genetic variation of some Norway spruce (Picea abies (L) Karst) forest genetic resources. Annals of Forest Research 45: 67-77.

Florescu I., Chițea G., Spârchez G., Dieter S., Petriţan I., Filipescu C., 2002. Particularities concerning the structuring and functioning of quasivirgine forest ecosystems in the Braşov mountains. Annals of Forest Research 45: 21-30.

Frank A., Howe G.T., Sperisen C., Brang P., St Clair B., Schmatz D., Heiri C., 2017. Risk of genetic maladaptation due to climate change in three major European tree species. Global Change Biology 23: 5358-5371. https://doi. org/10.1111/gcb.13802

Gardiner B., Quine C.P., 2000. Management of forests to reduce the risk of abiotic damage - A review with particular reference to the effects of strong winds. Forest Ecology and Management 135: 261-277. https://doi. org/10.1016/S0378-1127(00)00285-1
Giurgiu V., Decei I., Drăghiciu D., 2004. Metode şi tabele dendrometrice. Ceres Publishing House, Bucharest, 575 p [in Romanian].

Hayatgheibi H., Forsberg N.E.G., Lundqvist S.-O., Mörling T., Mellerowicz E., Karlsson B., Wu H., García-Gil R., 2018. Genetic control of transition from juvenile to mature wood with respect to microfibril angle in Norway spruce (Picea abies) and lodgepole pine (Pinus contorta). Canadian Journal of Forest Research 48: 1358-1365. https://doi. org/10.1139/cjfr-2018-0140

Héois B., Van De Sype H., 1991. Variabilité génétique de quinze provenances roumaines d'épicéa commun (Picea abies (L) Karst.). Premiers résultats. Annals of Forest Science 48: 179-192.

Hylen G., 1995. Age-age correlation and relative efficiency of early selection for wood density in young Norway spruce (Picea abies). Icelandic Agricultural Sciences 9: 123-124.

Isik K., Kleinschmit J., Steiner W., 2010. Age-age correlations and early selection for height in a clonal genetic test of Norway spruce. Forest Science 56: 212-221. https:// doi.org/10.1093/forestscience/56.2.212

Jansons Ā., Donis J., Danusevicius D., Baumanis I., 2015. Differential analysis for next breeding cycle for Norway spruce in Latvia. Baltic Forestry 21: 285-297.

Kapeller S., Dieckmann U., Schueler S., 2017. Varying selection differential throughout the climatic range of Norway spruce in Central Europe. Evolutionary Applications 10: 2538. https://doi.org/10.1111/eva.12413

Kauppi P.E., Posch M., Pirinen P., 2014. Large impacts of climatic warming on growth of boreal forests since 1960. PLoS One 9: e111340. https://doi.org/10.1371/journal. pone. 0111340

Keenan R.J., 2015. Climate change impacts and adaptation in forest management: a review. Annals of Forest Science 72: 145-167. https://doi.org/10.1007/s13595-014-0446-5

Keskitalo E.C.H., Bergh J., Felton A., Björkman C., Berlin M., Axelsson P., Ring E., Ågren A., Roberge J.M., Klapwijk M.J., 
et al., 2016. Adaptation to climate change in Swedish forestry. Forests 7(2): 28. https:// doi.org/10.3390/f7020028

Koskela J., Lefèvre F., Schueler S., Kraigher H., Olrik D.C., Hubert J., et al., 2013. Translating conservation genetics into management: Pan-European minimum requirements for dynamic conservation units of forest tree genetic diversity. Biological Conservation 157: 39-49. https://doi. org/10.1016/j.biocon.2012.07.023

Lefèvre F., Koskela J., Hubert J., Kraigher H., Longauer R., Olrik D.C., et al., 2013. Dynamic conservation of forest genetic resources in 33 European countries. Conservation Biology 27: 373-384. https:// doi.org/10.1111/j.1523-1739.2012.01961.x

Lines R., 1967. Standardization of methods for provenances research and testing. XIV IUFRO Congress, section III, Munich, pp. 672-719.

Loubère M., Saint-André L., Hervé J.-C., Vestøl G.I., 2004. Relationships between stem size and branch basal diameter variability in Norway spruce (Picea abies (L.) Karsten) from two regions of France. Annals of Forest Science 61: 525-535. https://doi.org/10.1051/forest:2004047

Marcu M., Budeanu M., Apostol E.N., Radu G.R., 2020. Valuation of the economic benefits from using genetically improved forest reproductive materials in afforestation. Forests 11(4): 382. https://doi.org/10.3390/ f11040382

Mensah A.A., Holmström E., Petersson H., Nyström K., Mason E.G., Nilsson U., 2021. The millennium shift: Investigating the relationship between environment and growth trends of Norway spruce and Scots pine in northern Europe. Forest Ecology and Management 481: 118727. https://doi. org/10.1016/j.foreco.2020.118727

Mihai G., 2009. Surse de seminţe testate pentru principalele specii de arbori forestieri din România [Tested seed sources for the main species of forest trees in Romania]. Silvică Publishing House, Bucharest, Romania, 281 p.

Nanson A., 2004. Génétique et amélioration des arbres forestières. Les presses agronomiques de Gembloux, Gembloux, Belgium, 712 p.

Pârnuţă G., 2008. Variabilitatea genetică și ameliorarea arborilor de molid cu coroană îngustă în România. Silvică Publishing House, Bucharest, Romania, 181 p.

Petersson H., 1997. Functions for predicting crown height of Pinus sylvestris and Picea abies in Sweden. Scandinavian Journal of Forest Research 12: 179-188.

Popa I., 2005. Wind throw-risk factor in mountainous forest ecosystems. Annals of Forest Research 48: 3-28.

Pretzsch H., Biber P., Schütze G., Kemmerer J., Uhl E., 2018. Wood density reduced while wood volume growth accelerated in Central European forests since 1870. Forest Ecology and Management 429: 589-616. https://doi. org/10.1016/j.foreco.2018.07.045

R Core Team, 2017. R: A language and environment for statistical computing. $\mathrm{R}$ foundation for statistical computing, Vienna, Austria. https:/www.R-project.org/ (accessed on 6 September 2020).

Rosner S., Světlík J., Andreassen K., Børja I., Dalsgaard L., Evans R., Karlsson B., Tollefsrud M.M., Solberg S., 2014. Wood density as a screening trait for drought sensitivity in Norway spruce. Canadian Journal of Forest Research 44: 154-161. https://doi.org/10.1139/cjfr-2013-0209

Ruotsalainen S., 2014. Increased forest production through forest tree breeding. Scandinavian Journal of Forest Research 29: 333-344. https://doi.org/10.1080/02827581.2 014.926100

Samariks V., Krisans O., Donis J., Silamikele I., Katrevics J., Jansons Ā., 2020. Cost-benefit analysis of measures to reduce windstorm impact in pure Norway spruce (Picea abies L. Karst.) stands in Latvia. Forests 11(5): 576. https://doi.org/10.3390/f11050576

Semeniuc A.I., Popa I., 2018. Comparative analysis of tree ring parameters variation in four coniferous species: (Picea abies, Abies alba, Pinus sylvestris and Larix decidua). International Journal of Conservation Science 9: 591-598. 
Šilinskas B., Varnagirytè-Kabašinskienè I., Aleinikovas M., Beniušienė L., Aleinikovienè J., Škèma M., 2020. Scots pine and Norway spruce wood properties at sites with different stand densities. Forests 11: 587. https://doi.org/10.3390/f11050587

Skrøppa T., Steffenrem A., 2019. Genetic variation in phenology and growth among and within Norway spruce populations from two altitudinal transects in MidNorway. Silva Fennica 53: 1-19. https://doi. org/10.14214/sf.10076

Snepsts G., Kitenberga M., Elferts D., Donis J., Jansons Ā., 2020. Stem damage modifies the impact of wind on Norway spruces. Forests 11(4): 463. https://doi.org/10.3390/ f11040463

STATISTICA 10.0., 2010. StatSoft Inc., Tulsa, OK, USA.

Steffenrem A., Saranpää P., Lundqvist S.O., Skrøppa T., 2007. Variation in wood properties among five full-sib families of Norway spruce (Picea abies). Annals of Forest Science 64: 799-806. https://doi. org/10.1051/forest:2007062

Steffenrem A., Solheim H., Skrøppa T., 2016. Genetic parameters for wood quality traits and resistance to the pathogens Heterobasidion parviporum and Endoconidiophora polonica in a Norway spruce breeding population. European Journal of Forest Research 135: 815-825. https://doi.org/10.1007/s10342016-0975-6

Suvanto S., Peltoniemi M., Tuominen S., Strandstöm M., Lehtonen A., 2019. Highresolution mapping of forest vulnerability to wind for disturbance-aware forestry. Forest Ecology and Management 453: 117-159. https://doi.org/10.1101/666305

Şofletea N., Budeanu M., 2015. Response of Norway spruce (Picea abies) seed stand progenies tested under different site conditions. Šumarski List 1-2: 47-57.

Şofletea N., Budeanu M., Pârnuță G., 2012. Provenance variation in radial increment and wood characteristics revealed by 30 years old Norway spruce comparative trials. Silvae Genetica 61: 170-178.
Şofletea N., Curtu A.L., 2007. Dendrologie. "Transylvania" University Publishing House, Braşov, Romania.

Ujvari E., Ujvari F., 2006. Adaptation of progenies of a Norway spruce provenance test (IUFRO 1964/68) to local environment. Acta Silvatica Lignaria Hungarica 2: 47-56. Van der Maaten-Theunissen M., Kahle H.P., van der Maaten E., 2013. Drought sensitivity of Norway spruce is higher than that of silver fir along an altitudinal gradient in southwestern Germany. Annals of Forest Science 70: 185-193. https://doi. org/10.1007/s13595-012-0241-0

Vitali V., Buntgen U., Bauhus J., 2017. Silver fir and Douglas fir are more tolerant to extreme droughts than Norway spruce in south-western Germany. Global Change Biology 23: 5108 5119. https://doi.org/10.1111/gcb.13774

Zeltinš P., Katrevičs J., Gailis A., Maaten T., Bāders E., Jansons Ā., 2019. Adaptation capacity of Norway spruce provenances in western Latvia. Forests 10(10): 840. https:// doi.org/10.3390/f10100840

Żółciak A., Oszako T., Sabor J., 2009. Evaluation of the health status of Picea abies provenances growing on the IUFRO 1964-68 experimental plots. Dendrobiology 61 (Supplement): 63-68.

Zubizarreta-Gerendiain A., Pellikka P., Garcia-Gonzalo J., Ikonen V.P., Peltola H., 2012. Factors affecting wind and snow damage of individual trees in a small management unit in Finland: Assessment based on inventoried damage and mechanistic modelling. Silva Fenniva 46: 181-196. https://doi.org/10.14214/sf.441. 